\title{
Kansas scientists help to oust creationists
}

Rex Dalton, San Diego

Direct action by scientists has helped secure a victory against the US creationist movement. A grassroots campaign seems to have played a key role in ousting three anti-evolutionists from the Kansas Board of Education, clearing the way for evolution to be taught in the state's classrooms.

Last year, the board dropped the requirement to teach biological evolution and geological theories about the Earth's formation from the school curriculum (see Nature 400, 701; 1999).

But during an election campaign for board members that has been closely watched nationally and abroad, scientists many new to political activity — campaigned in voting districts and led public education campaigns in protest.

Partly as a result, three creationist board members were dropped in last week's primary election, held to select Republican party candidates for the general election in November.

Some Kansas scientists say the campaign is a model for future elections. Before, scientists largely ignored creationists and their political efforts. "This suggests a change in political activity," says Adrian Melott, an astrophysicist at the University of Kansas. "It shows that those who support enlightened

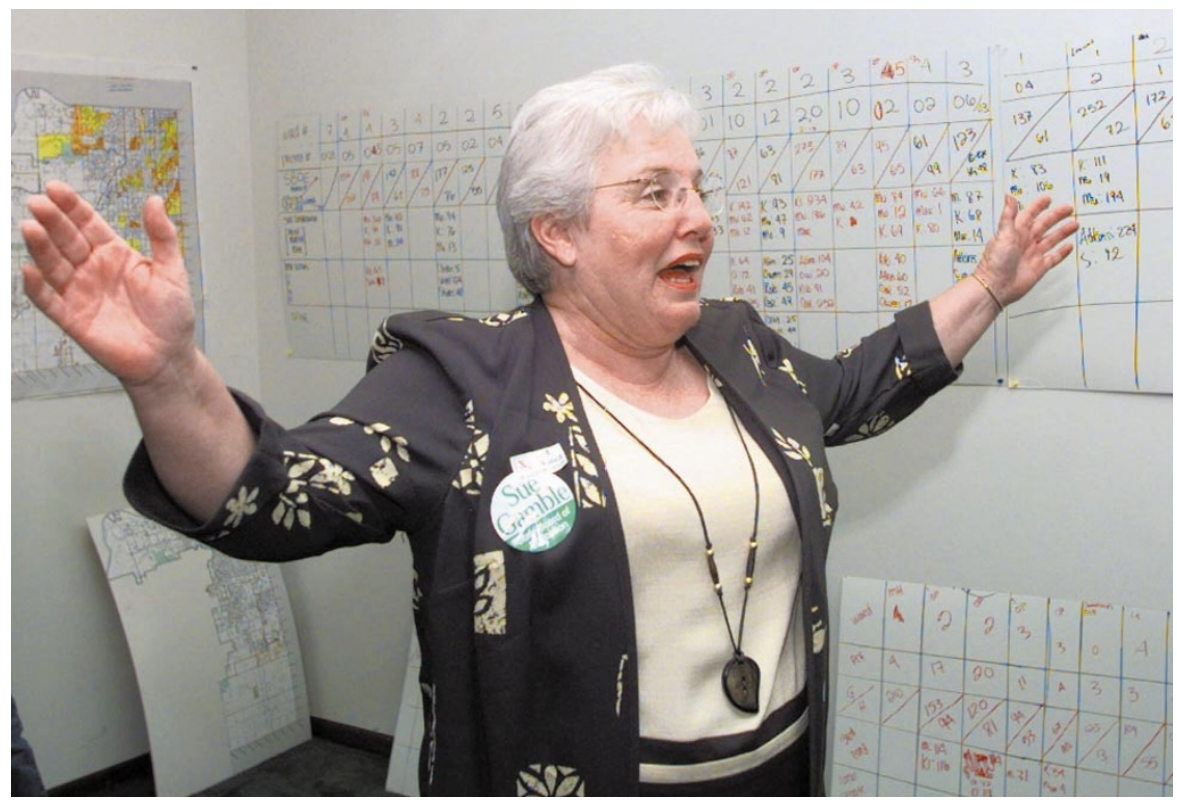

Heading for victory: Gamble (above) defeated anti-evolution school board head Linda Holloway.

values are as committed as the religious right wing; that could change American politics."

But campaigners say that their efforts cannot stop here. "We should treat this as a wakeup call, not a long-term victory," says Douglas Phenix, a member of the action group, who trained as a chemist at the University of Glas-

\section{From cell phones to brain cells}

A member of the family that founded one of the United States' first cellular telephone companies is to endow a brain research institute at the University of Washington in Seattle. A range of scientific disciplines there will focus on the neurological development of infants and children.

The Talaris Research Institute is being set up next to the university with a \$91 million donation from Jolene and Bruce McCaw. Bruce McCaw is one of four brothers involved in setting up McCaw Cellular Communications, which was sold for \$11.5 billion to AT\&T in 1994.

According to institute officials, plans call for at least 14 principal investigators to conduct research in areas ranging from molecular biology to experimental psychology. The newly constructed laboratories and facilities will be staffed by 100 support personnel.

The McCaw donation will consist of $\$ 16$ million to buy a former Battelle institute site, $\$ 50$ million to build new facilities over the next three years, and $\$ 5$ million in annual operating costs for five years. Institute scientists will look to major funding agencies for research grants.

Talaris has already hired two researchers from the University of Washington as scientific co-directors - the wife-andhusband team of Patricia Kuhl, former head of speech and hearing, and Andrew Meltzoff, head of developmental psychology.

Molecular biologist John Medina will be chief executive, and board chairman is Samuel Smith, a plant pathologist and president emeritus of Washington State University.

The new institute will "combine the science of learning with the practice of learning," says Medina. He adds that the ways in which infants and young children acquire and process information will be of particular interest.

"The research will be strongly interdisciplinary, combining the efforts of neuroscientists, molecular biologists, cognitive psychologists, computer scientists and educational researchers," says Medina. "The goal is to understand inherent cognitive and neurological informationprocessing features in infants and small children." gow, Scotland, and is now a Presbyterian minister in Kansas.

Kansas - dominated by the Republican party and home to many fundamentalist religious groups - became the latest battleground over evolution last year when a right-wing majority on the state school board quietly dropped evolution from state standards.

The move brought the state international embarrassment. Scientists are said to have rejected jobs at universities; businesses declined to open high-tech facilities there; and Kansas scientists claim to have been humiliated by criticism. This led to the formation of groups such as the scientistorganized Kansas Citizens for Science that helped produce last week's victory.

In the Republican party primary, four board members in the creationist majority were up for election. Three of them, including board president Linda Holloway, were beaten by pro-evolution candidates.

Given the expected make-up of the ten-person state school board, this assures a pro-evolution majority after November's general election, when the Republican candidates will face pro-evolution Democrats. As a result, the school board is expected to rewrite education standards to include evolution and associated subjects, officials say.

Holloway - whose campaign cost nearly three times as much as that of her challenger, Sue Gamble - was rejected by $60 \%$ of the voters in the Kansas City area, the state's major urban centre. Some claim that even more significant is the victory of pro-evolution Carol Rupe in Wichita, given the conservative voting record in that rural region.

Among those working to mobilize the 
pro-evolution vote in rural areas was Pat Ross, an assistant professor of biology at Southwestern College in the small town of

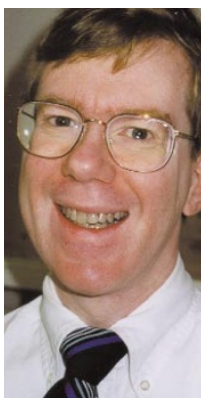

Buechner: spent this summer campaigning.
Winfield, Kansas. A member of Kansas Citizens for Science, Ross campaigned and helped organize a faculty vote against the state board's anti-evolution stance.

Southwestern is affiliated with the Methodist church, and was the only religious college in the state to have the faculty take such a position. "Typically, researchers are so immersed in their

own science that they assume people will see the light, so scientists don't need to get involved," says Ross. "This experience shows us scientists need to go outside their institutions and classrooms."

Another researcher who left the lab to fight the creationists was Matthew Buechner, a cell biologist at the University of Kansas. Appalled by the state board's actions, Buechner spent this summer campaigning door-to-door in conservative voting districts.

Buechner has already signed up to help with long-term education efforts for highschool teachers - the next phase of : activism by Kansas Citizens for Science.

\section{German scientists pledge to fight growing xenophobia}

Quirin Schiermeier \& Ute Gitschel, Munich

In a bid to counter the impression that foreign researchers face an unfriendly reception, Germany's scientific community has promised to fight the country's growing reputation for intolerance towards foreigners.

There have been several attacks and verbal assaults in the past months on foreign scientists and their families in east Germany. In Saxony, a young scientist was badly injured when right-wing extremists set their dog on him. Scientists have also been attacked in Gaterslaben and Frankfurt/Oder.

In an open letter published last week in German national newspapers, scientific institutes across the country warned that xenophobia and racism could threaten Germany's attractiveness to foreign scientists.

The letter's signatories include Hubert Markl, president of the Max Planck Society, and Frank Pobell, president of the Wissenschaftsgemeinschaft Gottfried Wilhelm Leibniz (WGL), an association of 80 research and service institutes. Several hundred foreign researchers come to Max Planck and WGL institutes in east Germany each year.

"Foreign scientists feel increasingly unsafe, particularly in eastern Germany," says
Falk Fabich, director of the Forschungsverbund Berlin, an association of eight Berlinbased WGL institutes that employ 85 foreign researchers and host around 300 guest researchers each year.

Fabich, who initiated the anti-racism campaign, says scientists are becoming "increasingly hesitant" about coming to Germany. For example, he says, the Alexander von Humboldt Foundation, which awards grants to foreign scholars, finds it increasingly difficult to arrange fellowships in east Germany. A programme director at the foundation says that fear of racist attack is "one of the reasons" people prefer to go elsewhere.

"If you look Asian or dark-skinned, you can feel the tension as soon as you leave the institute," says Dierk Scheel, director of the Institute for Plant Biochemistry in Halle, which has hosted Humboldt scholars from Asian countries in previous years.

Many German scientists are promising to fight against xenophobia. The Institute for Innovative Microelectronics in Frankfurt/ Oder in east Germany, for example, has organized meetings with schoolchildren to explain the economic benefits of international collaboration.

\section{Internet is the new key for restructured film institute}

Since the pioneering days of cinematography, film has been used by scientists to document, analyse and teach about complex phenomena, from the social behaviour of tribes to the growth of tumour cells.

But many national and private audiovisual service institutions - including those in the Netherlands, Austria, Hungary and Japan - have been closed over the past decade owing to the high cost of storing, preserving and distributing celluloid film.

Two years ago, Germany's only institute for scientific film, the Institut für den Wissenschaftlichen Film (IWF) in Göttingen, faced a similar fate. Its days seemed numbered after Germany's science council, the Wissenschaftsrat, criticized its failure to invest in new electronic media, and recommended that federal funding be withdrawn (see Nature 391, 425; 1998).

But a strategy based on embracing the opportunities offered by the Internet - and a $50 \%$ cut in its annual budget, provided jointly by federal and regional governments, to DM7 million (US\$3.2 million) - has helped the IWF to survive. The institute has now begun to create an online video library

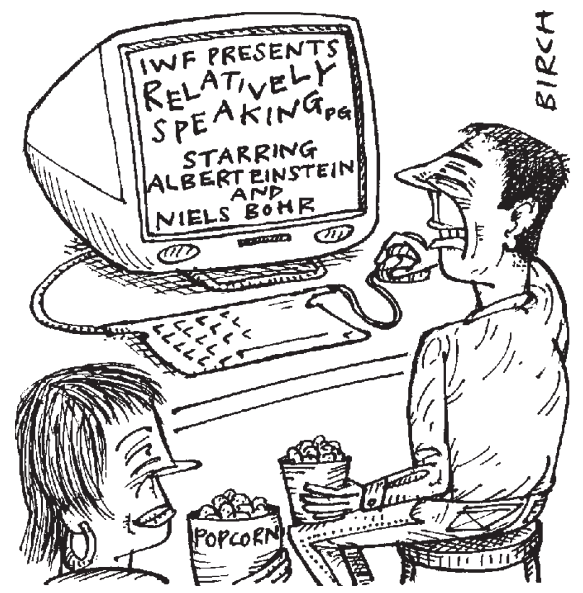

that is available to scientists, science teachers, film editors and producers worldwide.

The federal research ministry last month approved an additional DM5 million grant for the digitalization of the IWF's collection of around 7,000 films and video tapes, 5,000 of which were made at the IWF. Most of these recordings are visual aids for research and edycation in manyareas of science, medicine, anthropology and psychology.
Digitalization will start with the IWF's 400 most frequently requested films, including recordings of the activities in potassium ion channels and of material transport by North Sea currents.

These films, to be cut into about 1,000 two-minute sequences, will be online next spring, says Hartmut Rudolph, the institute's scientific director. By 2005, around 30,000 minutes of film should be available on the Internet, he says. The content of all available recordings will be scientifically annotated, and orders for clips will be taken online.

The IWF will no longer receive a fixed budget for producing new films, but must generate its own revenue. Rudolph hopes that the Internet library will help increase sales to commercial users. "We will of course continue to be a service institute for scientists," says Rudolph. "But financially we have become increasingly dependent on licensing our films to commercial users."

The institute is already licensing recordings to TV stations in Germany and to the BBC in Britain. http://wwww.iwf.de 